\title{
Antitumor Potential of Lippia citriodora Essential Oil in Breast Tumor-Bearing Mice
}

\author{
Katerina Spyridopoulou ${ }^{1}\left(\mathbb{D}\right.$, Tamara Aravidou ${ }^{1}$, Evangeli Lampri ${ }^{1}$, Eleni Effraimidou ${ }^{2}$, Aglaia Pappa ${ }^{1}(\mathbb{D}$ \\ and Katerina Chlichlia $1, *$ (D) \\ 1 Department of Molecular Biology and Genetics, Democritus University of Thrace, \\ University Campus-Dragana, 68100 Alexandroupolis, Greece; aikspiridopoulou@gmail.com (K.S.); \\ tamara.arav@gmail.com (T.A.); evangeli.lampri@gmail.com (E.L.); apappa@mbg.duth.gr (A.P.) \\ 2 Department of Medicine, Democritus University of Thrace, University Campus-Dragana, \\ 68100 Alexandroupolis, Greece; eeffraem@med.duth.gr \\ * Correspondence: achlichl@mbg.duth.gr; Tel.: +30-25510-30630
}

Citation: Spyridopoulou, K.; Aravidou, T.; Lampri, E.; Effraimidou, E.; Pappa, A.; Chlichlia, K. Antitumor Potential of Lippia citriodora Essential Oil in Breast Tumor-Bearing Mice. Antioxidants 2021, 10, 875. https:// doi.org/10.3390/antiox10060875

Academic Editor: Sergio

Granados-Principal

Received: 10 May 2021

Accepted: 26 May 2021

Published: 30 May 2021

Publisher's Note: MDPI stays neutral with regard to jurisdictional claims in published maps and institutional affiliations.

Copyright: (c) 2021 by the authors. Licensee MDPI, Basel, Switzerland. This article is an open access article distributed under the terms and conditions of the Creative Commons Attribution (CC BY) license (https:// creativecommons.org/licenses/by/ $4.0 /)$.

\begin{abstract}
Lippia citriodora is a flowering plant cultivated for its lemon-scented leaves and used in folk medicine for the preparation of tea for the alleviation of symptoms of gastrointestinal disorders, cold, and asthma. The oil extracted from the plant leaves was shown to possess antioxidant potential and to exert antiproliferative activity against breast cancer. The aim of this study was to further investigate potential antitumor effects of L. citriodora oil (LCO) on breast cancer. The in vitro antiproliferative activity of LCO was examined against murine DA3 breast cancer cells by the sulforhodamine B assay. We further explored the LCO's pro-apoptotic potential with the Annexin-PI method. The LCO's anti-migratory effect was assessed by the wound-healing assay. LCO was found to inhibit the growth of DA3 cells in vitro, attenuate their migration, and induce apoptosis. Finally, oral administration of LCO for 14 days in mice inhibited by $55 \%$ the size of developing tumors in the DA3 murine tumor model. Noteworthy, in the tumor tissue of LCO-treated mice the apoptotic marker cleaved caspase-3 was elevated, while a reduced protein expression of survivin was observed. These results indicate that LCO, as a source of bioactive compounds, has a very interesting nutraceutical potential.
\end{abstract}

Keywords: Lippia citriodora; essential oil; antiproliferative effect; antimigratory activity; breast cancer; oral administration

\section{Introduction}

Being stationary autotrophs, plants need to overcome a variety of challenges such as herbivores, pathogens, and the need for a steady flow of nutrients despite the environmental changes. In order to cope with the various stresses and damages induced by a dynamic environment, plants have evolved to synthesize secondary metabolites that allow them to interact with their environment [1,2]. These low-molecular-weight substances, which can be species- or genera-specific [2], represent a huge and heterogeneous group of bioactive compounds, used as high-value chemicals [3].

Plant secondary metabolites are a unique source for pharmaceuticals [4], insecticides [5], flavoring agents, dyes, etc. [3]. Noteworthy, various bioactivities were identified in different phytochemicals such as antibacterial [6], antiviral [7], antifungal [8], antioxidant [9], and anti-inflammatory [10] activities. Most importantly, several plant extracts exert significant antitumor effects, namely, antiproliferative, redox regulating, cell cycle arrest-inducing, anti-migratory, and pro-apoptotic [11-14]. Carcinogenesis and tumor growth are complex processes that involve various mechanisms and the recruitment of a diverse range of molecules. Phytochemicals, being functionally pleiotropic, may lead to simultaneous targeting of the various events/pathways involved in cancer development and progression [15]. Certain dietary phytochemicals, besides their direct antitumor effects, were shown to 
enhance the therapeutic potency of chemotherapeutic agents [16]. Crucially, the anticancer properties of various phytochemicals were linked to their antioxidant activity [17].

Lippia citriodora is a flowering subshrub/shrub, native in South America, that was introduced in Europe at the end of 17th century [18]. The plant is also known as Lippia triphylla, Verbena triphylla, Aloysia triphylla, Aloysia citriodora, Verbena citriodora, or Lemon verbena. L. citriodora is mostly cultivated for its lemon-scented leaves, traditionally used in folk medicine for the alleviation of gastrointestinal symptoms, fever, cold, asthma, diabetes, spasms, insomnia, and anxiety $[19,20]$. Plant extracts were shown to exert significant antioxidant activity that was associated with their flavonoid and phenolic content [21-24]. Antioxidant properties of $L$. citriodora were evaluated in various in vitro, ex vivo, or in vivo systems, employing different biochemical assays. L. citriodora infusion was shown to act as a free radical scavenger against superoxide, hydroxyl radicals, and hypochlorous acid [23]. Aqueous extracts of the plant were shown to inhibit the ABTS (2,2'-azino-bis(3-ethylbenzothiazoline6-sulphonic acid)) and DPPH (2,2-Diphenyl-1-picrylhydrazyl) radicals and protect against protein carbonylation and lipid peroxidation in Wistar rat brain homogenates [25], while alcoholic and aqueous extracts, upon oral administration, were shown to elevate the blood glutathione levels in the alloxan-induced diabetic rat model [26]. Noteworthy, both the essential oil investigated in this study as well as citral, a mixture of two terpenoid isomers that was identified as the oil's main constituent, were shown to inhibit the $\mathrm{H}_{2} \mathrm{O}_{2}$-induced oxidative damage in human Jurkat T-leukemia cells [27]. Besides the plant's well-documented antioxidant potential, recent studies demonstrate that various extracts from L. citriodora have the potential to inhibit the growth of cancer cells in vitro [27-30]. Moreover, citral, the main constituent of the essential oil from L. citriodora [27], exerts antitumor activity in murine breast cancer models upon oral administration [31,32].

Breast cancer is the most frequent cancer and the leading cause of cancer death in women [33]. Because of the heterogeneity of breast cancer as a disease, treatment protocols and prognosis vary greatly between different patients [34]. Several important risk factors for breast cancer such as menopause, aging, genetic predisposition or estrogens, have been associated with oxidative stress [35]. Consecutively, it has been proposed that compounds with antioxidant potential such as the various extracts from L. citriodora discussed above could prevent certain biochemical processes that lead to breast cancer development [36].

Therefore, the aim of this work was to examine the potential antitumor effects against breast cancer of the essential oil extracted from the leaves of L. citriodora (LCO) as a plantspecific mixture of various bioactive compounds. Specifically, we assayed the potential growth inhibitory, anti-migratory, and pro-apoptotic activities of the essential oil in vitro. Moreover, we examined whether oral administration of the oil attenuates growth of breast cancer in vivo in the experimental DA3 mouse tumor model.

\section{Materials and Methods}

\subsection{Plant Material and Essential Oil Extraction}

Collection and identification of plant material was described in a previous study by our team regarding the biological properties of Lippia citriodora oil [27]. Briefly, plant samples of small shrubs were purchased by Vioryl S.A. from an herbal market (Afidnes, Athens, Greece), identified as Lippia citriodora by a botanist, and planted and maintained in pots until their first inflorescence in May/June when the leaves and stems were collected. The collected parts of the herb were subjected to hydrodistillation in a laboratory-scale, watersteam distillation apparatus as described in our team's previously published study [27]. The composition of the extracted oil was analyzed by Gas chromatography-mass spectrometry (GC-MS) (GC: 6890 A, Agilent Technologies, USA; MSD: 5973, Agilent Technologies, Santa Clara, CA, USA) using an HP- $1 \mathrm{~ms}$ column $(25 \mathrm{~m}, 0.2 \mathrm{~mm}$ i.d., $0.33 \mu \mathrm{m}$ film thickness). The detailed analysis process and chemical composition of the oil are described in Fitsiou et al. [27]. 


\subsection{Cell Line}

DA3 cells is a well-characterized tumor cell line that was derived from the D1-DMBA-3 mammary tumor, syngeneic to BALB/c mice [37]. The cells were maintained under sterile conditions at $37^{\circ} \mathrm{C}$ in a humidified atmosphere of $5 \% \mathrm{CO}_{2}$ in DMEM supplemented with $10 \%$ fetal bovine serum, penicillin $(100 \mathrm{U} / \mathrm{mL})$, and streptomycin $(100 \mu \mathrm{g} / \mathrm{mL})$.

\subsection{Animals}

Mice (BALB/c, female, $n=18$ ) that were $6-8$ weeks old and weighted $20-25 \mathrm{~g}$, were purchased from the Animal Facility of Pasteur Institute (Athens, Greece). Animals were housed in polycarbonate cages (maximum of 5 mice per cage) and maintained at room temperature, on a $12 \mathrm{~h}$ light- $12 \mathrm{~h}$ dark cycle at the Animal House of Medical School at the University of Ioannina (Greece). Tap water and a commercial, pelleted diet (Mucedola) were provided ad libitum to all animals. Animal experiments were approved by the Animal Care and Use Committee of the Veterinary Department of Ioannina Prefecture (license number EL20BIO02). All animal procedures were carried out in accordance with the principle of the 3 Rs (replacement, refinement, reduction) and all mice used were not subjected to any pain or discomfort.

\subsection{DA3 Experimental Tumor Model}

Mice were separated into two independent groups (nine mice per group) and a previously described treatment protocol was followed $[9,11,12,38,39]$. Briefly, LCO was administered per os by oral gavage at a daily dose of $0.552 \mathrm{~g} / \mathrm{kg}$ of animal body weight diluted in a final volume of $150 \mu \mathrm{L}$ of corn oil (vehicle), for 14 days. Animals in the control group received an equal volume of plain corn oil. Mice were monitored daily for weight fluctuations and signs of discomfort or disease. DA3 cells $\left(5 \times 10^{6}\right)$ were injected subcutaneously, in the scruff of mice's necks on the 12th day of LCO administration. Animals were euthanized by cervical dislocation on the 7th day post cancer cells inoculation. Developed tumors, spleens, and livers were surgically removed from all animals. The organs were weighed and tumor dimensions were defined by an electronic micrometer. Tumor volume was calculated by the modified ellipsoid formula $\left(\mathrm{mm}^{3}\right)$ :

$$
\text { Tumor volume }=0.5 \times\left(\text { width }{ }^{2} \times \text { length }\right)
$$

\subsection{Chemicals and Reagents}

Acetic acid, dimethyl sulfoxide (DMSO), trichloroacetic acid (TCA), sulforhodamine B (SRB) and Trizma base were purchased from Sigma-Aldrich (St. Louis, MO, USA); Annexin V-PI kit was purchased from BD Biosciences (Franklin Lakes, NJ, USA); Dulbecco's Modified Eagle's Medium (DMEM) and phosphate-buffered saline (PBS) were purchased from Gibco (Thermo Fisher Scientific, Waltham, MA, USA); trypsin, fetal bovine serum (FBS) and penicillin/streptomycin, were purchased from Biosera (Boussens, France). Formalin and Hematoxylin were purchased from Merck (Merck Millipore, Billerica, MA, USA) and eosin, xylole and paraffin were purchased from Diapath (Martinengo BG, Italy). DAB (3,3'-Diaminobenzidine) was purchased from Dako (Agilent Technologies, Santa Clara, CA, USA). All antibodies were purchased from Cell Signaling (Danvers, MA, USA).

\subsection{Cell Growth Assay}

Cell growth rate was analyzed by the Sulforhodamine B (SRB) assay [40], as previously described [11]. Briefly, 8000 DA3 cells were seeded per well in a 96-well plate. Cells were exposed to a wide range of increasing LCO concentrations $(0-0.92 \mathrm{mg} / \mathrm{mL})$ dissolved in $\operatorname{DMSO}(1: 1 v / v)$, for 24,48 , or $72 \mathrm{~h}$. Control cells were incubated in DMSO-containing DMEM (DMSO concentration $\leq 0.1 \% v / v$ ). After treatment, cells were fixed with TCA for $1 \mathrm{~h}$ and stained with SRB dissolved in acetic acid for $30 \mathrm{~min}$. Tris base was added in SRBstained cells in order to dissolve the SRB cell-bound stain before measuring the samples' absorbance (optical density, OD) at $492 \mathrm{~nm}$. For the OD measurement, a microplate reader 
(Enspire, Perkin Elmer) was employed. Results presented are representative of at least three independent experiments. The $\mathrm{IC}_{50}$ values were calculated using the Sigma Plot software v.11. The \% inhibition of cell growth was calculated by the following formula:

$$
\% \text { growth }=(\text { mean OD sample }) /(\text { mean OD control } \times 100)
$$

\subsection{Wound-Healing Assay}

DA3 cells were seeded in 12-well plates at a seeding density of $3 \times 10^{5}$ cells/well. After $24 \mathrm{~h}$, when a confluent monolayer was formed, a $10 \mu \mathrm{L}$ pipette tip was used to scratch the monolayer across the well. Next, monolayers were washed with PBS so that the detached cells could be removed and either DMSO (DMSO concentration $\leq 0.1 \% v / v$ ) for control cells or LCO-containing medium for treated cells was added to the wells. To exclude the growth inhibitory effect of LCO as a potential mechanism of wound-healing inhibition, non-toxic concentrations were used (as determined by the SRB assay) for the treatment of the cells. Specifically, cells were treated with $46 \mu \mathrm{g} / \mathrm{mL}$ of LCO. Cells were photographed with a light microscope (Zeiss, Göttingen, Germany) that was equipped with a digital camera. Multiple photographs per time point were analyzed with ImageJ software (NIH, Bethesda, MD, USA) from three independent experiments and the average $\%$ wound area (\% open image area) was calculated.

\subsection{Flow Cytometric Analysis of Apoptosis by Annexin V and Propidium Iodide Staining}

Detection of apoptotic cells was performed using the Annexin V-PI double staining method [41]. A commercially available kit was used according to the manufacturer's instructions. Briefly, cells were seeded in 6-well plates at a seeding density of $2 \times 10^{5}$ cells/well. After an overnight incubation, cells were treated with 89 or $184 \mu \mathrm{g} / \mathrm{mL}$ of LCO for 24,48 , or $72 \mathrm{~h}$. Cells treated with appropriate DMSO (vehicle) concentrations were used as control. Following collection, cells were stained and analyzed on an Attune NxT flow cytometer (Thermo Fisher Scientific, Waltham, MA, USA). Data obtained were analyzed using FlowJo V10 software (Tree Star, Inc., Ashland, OR, USA).

\subsection{Immunohistochemical Analysis}

Excised tumors were fixed in 10\% formalin before being dehydrated in graded concentrations of ethanol, xylole, and embedded in paraffin. Paraffin tissue blocks were cut into $3 \mu \mathrm{m}$ thick sections with a microtome. Next, the sections were mounted onto charged glass slides. An hematoxylin and eosin stained section was obtained from each tissue block. Immunostaining was performed based on streptavidin-biotin peroxidase labeled method. Deparaffinization and hydratation were done by immersing the tissue sections into graded concentrations of ethanol to deionized water. Primary antibodies, against survivin (\#2808 Cell Signaling, dilution 1:50) or cleaved caspase 3 (\#9661 Cell Signaling, dilution 1:1000), were then applied to the tissues and incubated overnight at $4{ }^{\circ} \mathrm{C}$. Immunoreactivity was visualized with $3,3^{\prime}$-Diaminobenzidine (DAB) followed by counterstaining with hematoxylin. For negative controls, the primary antibody was omitted. An image analysis system composed of the Olympus BX43 upright microscope, digital camera Olympus Cam-SC30 (Olympus Europa, Hamburg, Germany) and soft analysis (analySISH) was used. Two observers selected at least 10 representative regions from all the sections of each case, where immunopositive tumor cells were counted by using the $\times 40$ objective lens, adopting a continuous score system. The expression was defined as the percentage of positive cells in the total number of the counted cells (number of immunopositive cells/total number of the counted cells).

\subsection{Statistical Analysis}

Data are representative of at least three independent experiments and are presented as mean \pm SD. For statistical analysis and graphing, the Sigma Plot v.11 software (Systat Software Inc., San José, CA, USA) was used unless stated otherwise. For statistical comparisons between groups Student's $t$-test or Mann-Whitney test for non-parametric variables 
were performed. Differences between groups were considered significant when $p<0.05$ $\left({ }^{*} p<0.05,{ }^{* *} p<0.01,{ }^{* *} p<0.001\right)$.

\section{Results and Discussion}

\subsection{Chemical Composition of LCO}

Volatile profile analysis by GC-MS conducted by our team identified the composition of LCO, which was described in detail in a previous published study [27]. Briefly, 43 compounds representing the $87 \%$ of the total chromatographic area were identified. The two major compounds were determined to be geranial (trans-citral) and neral (cis-citral), reported as citral, which is the sum of the two isomers (Table 1). Neral and geranial accounted for $17.2 \%$ or $26.4 \%$, respectively, of the total chromatographic area, which is in accordance with the literature where citral was previously reported as one of the main components of the oil extracted from plants of the citriodora species [18]. Noteworthy, the trans-isomer geranial which is 1.5 times more abundant in LCO than neral, was reported to exert more potent antitumor properties as compared to the cis-isomer, neral [42]. Interestingly, L. citriodora oil with a similar composition was previously shown to possess antioxidant properties [22], while our team investigated the antioxidant potential of LCO and reported its ability to protect Jurkat cells against $\mathrm{H}_{2} \mathrm{O}_{2}$-induced oxidative damage as well as LCO's moderate direct antioxidant activity analyzed by the DPPH and ABTS assays [27].

Table 1. The 10 most abundant volatile compounds identified in Lippia citriodora essential oil (LCO) by GC-MS analysis. Data reproduced from Fitsiou et al. [27].

\begin{tabular}{|c|c|c|c|c|c|}
\hline $\mathrm{KRI}^{\mathrm{a}}$ & Compounds & $\%$ Area & Structure & Formula & $\mathrm{MW}^{\mathrm{b}}(\mathrm{g} / \mathrm{mol})$ \\
\hline 1246 & Geranial (trans-citral) & 26.404 & & $\mathrm{C}_{10} \mathrm{H}_{16} \mathrm{O}$ & 152.23 \\
\hline 1215 & Neral (cis-citral) & 17.16 & & $\mathrm{C}_{10} \mathrm{H}_{16} \mathrm{O}$ & 152.23 \\
\hline 1212 & Nerol & 8.047 & & $\mathrm{C}_{10} \mathrm{H}_{18} \mathrm{O}$ & 154.25 \\
\hline 1241 & Geraniol & 5.72 & & $\mathrm{C}_{10} \mathrm{H}_{18} \mathrm{O}$ & 154.25 \\
\hline 1551 & Spathulenol & 3.279 & & $\mathrm{C}_{15} \mathrm{H}_{24} \mathrm{O}$ & 220.35 \\
\hline 1008 & 1,8-Cineol & 3.15 & & $\mathrm{C}_{10} \mathrm{H}_{18} \mathrm{O}$ & 157.27 \\
\hline 954 & 6-Methyl-5-hepten-2-one & 2.278 & & $\mathrm{C}_{8} \mathrm{H}_{14} \mathrm{O}$ & 126.2 \\
\hline 1010 & Limonene & 2.166 & & $\mathrm{C}_{10} \mathrm{H}_{16}$ & 136.23 \\
\hline
\end{tabular}


Table 1. Cont.

\begin{tabular}{cccccc}
\hline KRI $^{\mathbf{a}}$ & Compounds & \% Area & Structure & Formula $^{2}$ & $\mathbf{M W}^{\mathbf{b}}\left(\mathrm{g} / \mathbf{m o l}^{\prime}\right)$ \\
\hline 1464 & Ar-curcumene & 2.098 & $\mathrm{C}_{15} \mathrm{H}_{22}$ \\
\hline
\end{tabular}

${ }^{a}$ KRI: Kovats Retention Indices, ${ }^{b}$ MW: Molecular Weight.

\subsection{Antiproliferative Activity of LCO}

LCO exhibited a dose- and time-dependent growth inhibitory activity against DA3 murine mammary adenocarcinoma cells (Figure 1 ). The $\mathrm{IC}_{50}$ values for 24,48 , or $72 \mathrm{~h}$ were determined to be $96.4 \pm 8.9,77.8 \pm 1.5$, or $70.7 \pm 5.5 \mu \mathrm{g} / \mathrm{mL}$, respectively (Table 2 ). The higher $\mathrm{IC}_{50}$ values for $24 \mathrm{~h}$ compared to 48 and $72 \mathrm{~h}$ and for $48 \mathrm{~h}$ compared to $72 \mathrm{~h}$ implied that the growth inhibitory effect exerted by LCO against DA3 cells was time dependent. Cytotoxicity of LCO was previously reported by our team against human melanoma A375, hepatic HepG2, breast MCF-7, and colonic Caco2 cancer cell lines. We also observed a moderate cytotoxic activity of LCO against THP-1 human leukemic cells' line $\left(\mathrm{EC}_{50}>100 \mu \mathrm{g} / \mathrm{mL}\right)$ [27], which is in agreement with the results reported by Escobar et al. [28]. LCO was also shown to inhibit the growth of murine P815 mastocytoma [29], human breast adenocarcinoma MDA-MB-231 cells, as well as chronic myelogenous erythroleukemia K562 and neuroblastoma SH-SY5Y cells [30]. Besides the essential oil extracted from the plant, various other L. citriodora extracts were reported to exert antiproliferative activity against cancer cell lines as well $[43,44]$. Noteworthy, L. citriodora extracts appear to exert cancer-specific, growth-inhibitory effects. Escobar et al. described that LCO did not significantly affect the proliferation rate of normal Vero monkey kidney cells [28]. The potential selective antiproliferative activity of L. citriodora extracts against cancer cells was also indicated by the cytotoxic effect of the herbal substance acteoside, isolated from $L$. citriodora leaves, against A5 murine metastatic spindle carcinoma cells. Interestingly, acteoside did not affect to the same extent the viability of C5N normal mouse keratinocytes [45]. Moreover, LCO exhibited moderate antiproliferative activity against human normal ESCs (endometrial stromal cells) [30]. Thus, even though there are only a few studies investigating the in vitro antiproliferative potential of LCO, these studies suggest that the oil extracted from L. citriodora exerts potent, diverse, and selective antitumor activities.
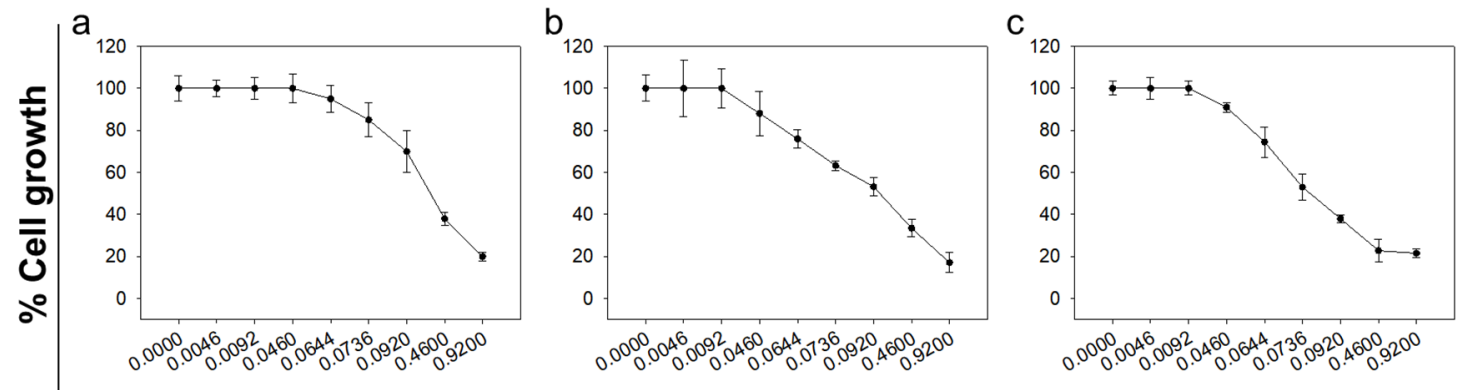

\section{LCO $\mathrm{mg} / \mathrm{ml}$}

Figure 1. In vitro anticancer activity of LCO. Antiproliferative effect of increasing doses of LCO at (a) $24 \mathrm{~h}$, (b) $48 \mathrm{~h}$, or (c) $72 \mathrm{~h}$ on DA3 murine breast cancer cells. Percentage (\%) of cell growth was analyzed by the SRB assay. All data shown are representative of at least three independent experiments. Values represent mean $\pm \mathrm{SD}$. 
Table 2. $\mathrm{IC}_{50}$ values (concentration that causes a 50\% inhibition in cell growth) of LCO against DA3 cells determined by the SRB assay after a 24-, 48-, or a 72-h treatment. Data are representative of at least three independent experiments and are presented as mean $\pm \mathrm{SD}$.

\begin{tabular}{ccc}
\hline IC $_{\mathbf{5 0}} \mathbf{( 2 4 )}$ & IC $_{\mathbf{5 0}}$ (48) & IC $_{\mathbf{5 0}}$ (72) \\
\hline $96.4 \pm 8.9 \mu \mathrm{g} / \mathrm{mL}$ & $77.8 \pm 1.5 \mu \mathrm{g} / \mathrm{mL}$ & $70.7 \pm 5.5 \mu \mathrm{g} / \mathrm{mL}$ \\
\hline
\end{tabular}

\subsection{Evaluation of the In Vitro Pro-Apoptotic Potential of LCO}

The interesting observation of the time-dependent, growth inhibitory effect of LCO led us to further investigate the potential mechanism involved. Interestingly, it has been reported in the literature that both the oil as a mixture [29] and acteoside, an herbal substance isolated from L. citriodora [45], may induce apoptosis in cancer cells. Moreover, citral, which has been identified as the major component of LCO [27], was reported to induce apoptosis in breast cancer cells in vitro and in vivo in murine tumor models [31,46]. Thus, we investigated the potential pro-apoptotic activity of LCO against DA3 cells by the flow cytometric analysis of Annexin V and propidium iodide (PI) double staining method for the identification of early apoptotic cells. Our results are in accordance with the literature and indicate that LCO induces morphological changes in cells that are typical during apoptosis in DA3 cells. Specifically, cells treated with 0.089 or $0.184 \mathrm{mg} / \mathrm{mL}$ of LCO for $24 \mathrm{~h}$ exhibited, compared to control, a $12 \%$ or $55 \%$ rise, respectively, in the ratio of early apoptotic to viable cells (Figure 2). Cells treated for $48 \mathrm{~h}$ exhibited an increase of $30 \%$ or $517 \%$, while cells treated for $72 \mathrm{~h}$ exhibited an increase of $10 \%$ or a decrease of $1 \%$ (as progressively, an increasing number of cells undergoes cell death) in the ratio of early apoptotic to viable cells for 0.089 or $0.184 \mathrm{mg} / \mathrm{mL}$ of LCO, respectively.

This observation indicates that LCO induces concentration-dependent apoptotic effects in DA3 cells.

Apoptosis is a mechanism that comprises a very significant target for anticancer therapy [47]. There have been previous reports on the pro-apoptotic activity of essential oils extracted from different plant species against various cancer cell lines $[11,48,49]$. These extracts, due to their diverse chemical composition, comprise a valuable source of bioactive compounds [50]. Our results indicate that LCO could be a good candidate for the identification of apoptosis-promoting phytochemicals.

\subsection{LCO Exerts Antimigratory Effects}

Furthermore, we investigated whether LCO affects migration of DA3 cells in vitro. Migration of cancer cells is a crucial step in cancer invasion and metastasis [51]. Identification of novel therapeutic compounds that have the potential to attenuate cancer cell migration could lead to the development of novel or combination anticancer strategies. Noteworthy, various phytochemicals have been reported to block migration of cancer cells in vitro $[11,12,52]$. Despite the lack of studies regarding the potential antimigratory effect of LCO, citral, the most abundant phytochemical in LCO, was shown to inhibit the migration of both human and murine breast cancer cells [32,53]. Thus, we employed the wound-healing assay in order to investigate whether LCO attenuates migration of DA3 cells. Noteworthy, the cells were treated with a non-toxic concentration of LCO $(46 \mu \mathrm{g} / \mathrm{mL})$ that, according to our SRB results (Figure 1), did not significantly affect cell growth. Our results indicate that it took more time for the LCO-treated cells to fill the open area compared to control cells (Figure 3). Specifically, the mean ratio of open area closure in control cells reached $94 \%$ after only $2 \mathrm{~h}$, while the LCO-treated group exhibited only a $58 \%$ of open-area-closure ratio in the same time point. Wound closure occurred after $3 \mathrm{~h}$ in control cells while the closure was not complete in LCO-treated cells that exhibited a remaining $15 \%$ of open image area. Considering the reported antimigratory activity of citral, LCO's observed migration-attenuating effect might be attributed to its major constituent. 

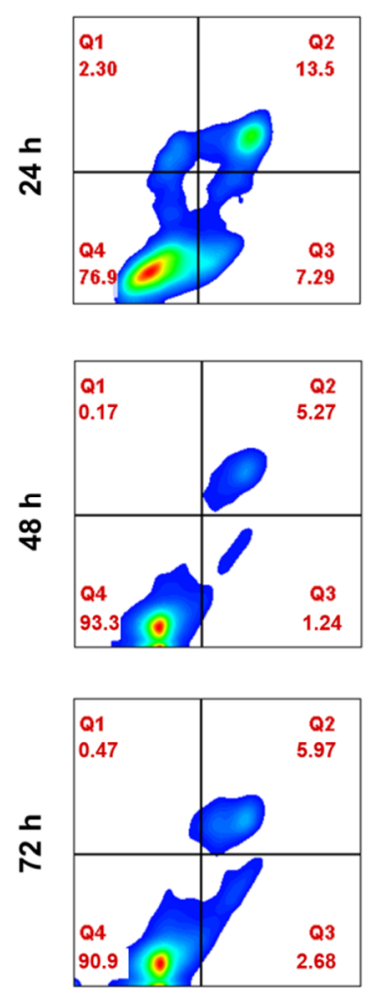

b
$0.089 \mathrm{mg} / \mathrm{mL}$
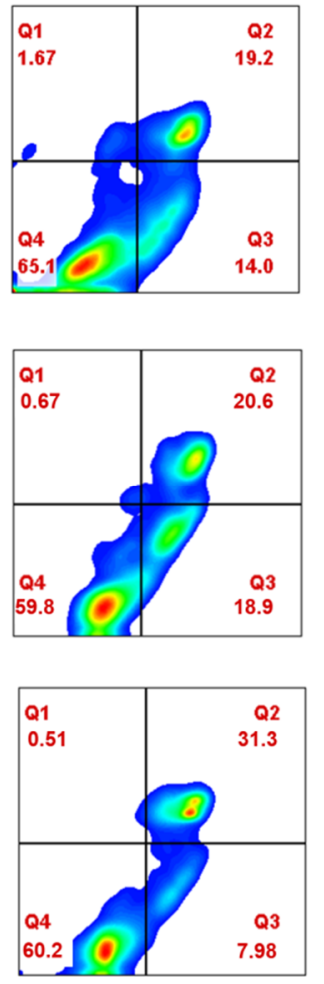

$0.184 \mathrm{mg} / \mathrm{mL}$
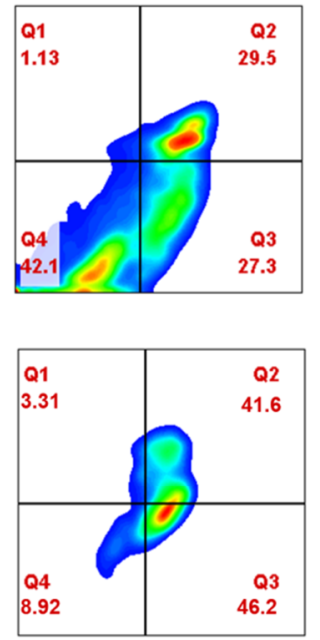

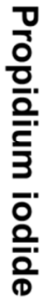

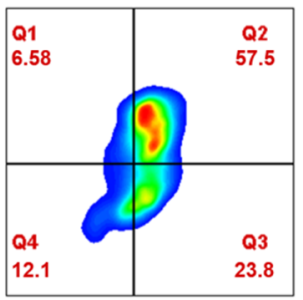

AnnexinV-FITC

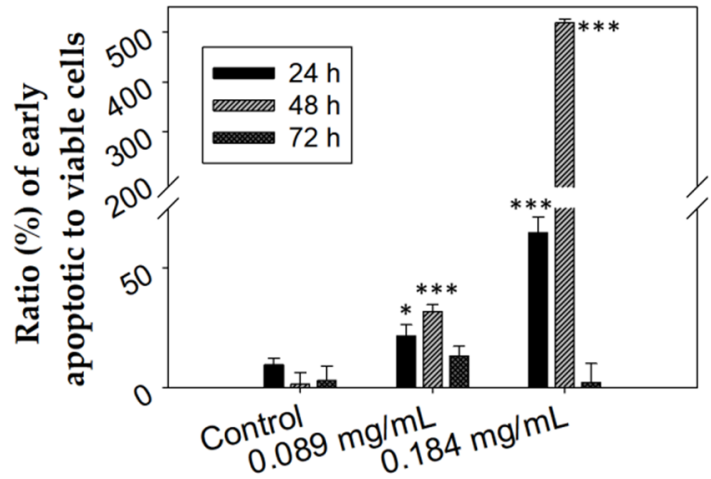

Figure 2. LCO induces apoptotic cell death in DA3 murine breast adenocarcinoma cells detected by flow cytometry. Cells were treated with 0.089 or $0.184 \mathrm{mg} / \mathrm{mL}$ of the LCO for 24,48 , or $72 \mathrm{~h}$ and stained with Annexin V-FITC and PI before being analyzed by flow cytometry. (a) Density plots of control and treated cells. The percentages of viable (Annexin V-FITC and PI negative), early apoptotic (Annexin V-positive and PI-negative), and late apoptotic/necrotic (Annexin V/PI double-positive) cells are indicated on the plots. (b) Percentage (\%) ratio of early apoptotic to viable cells. At least 10,000 cells were analyzed per sample. Results are presented as the mean \pm SD of three independent experiments. Asterisks indicate statistically significant difference between control and treated cells $\left({ }^{*} p<0.05,{ }^{* * *} p<0.001\right.$ Student's $t$-test). 


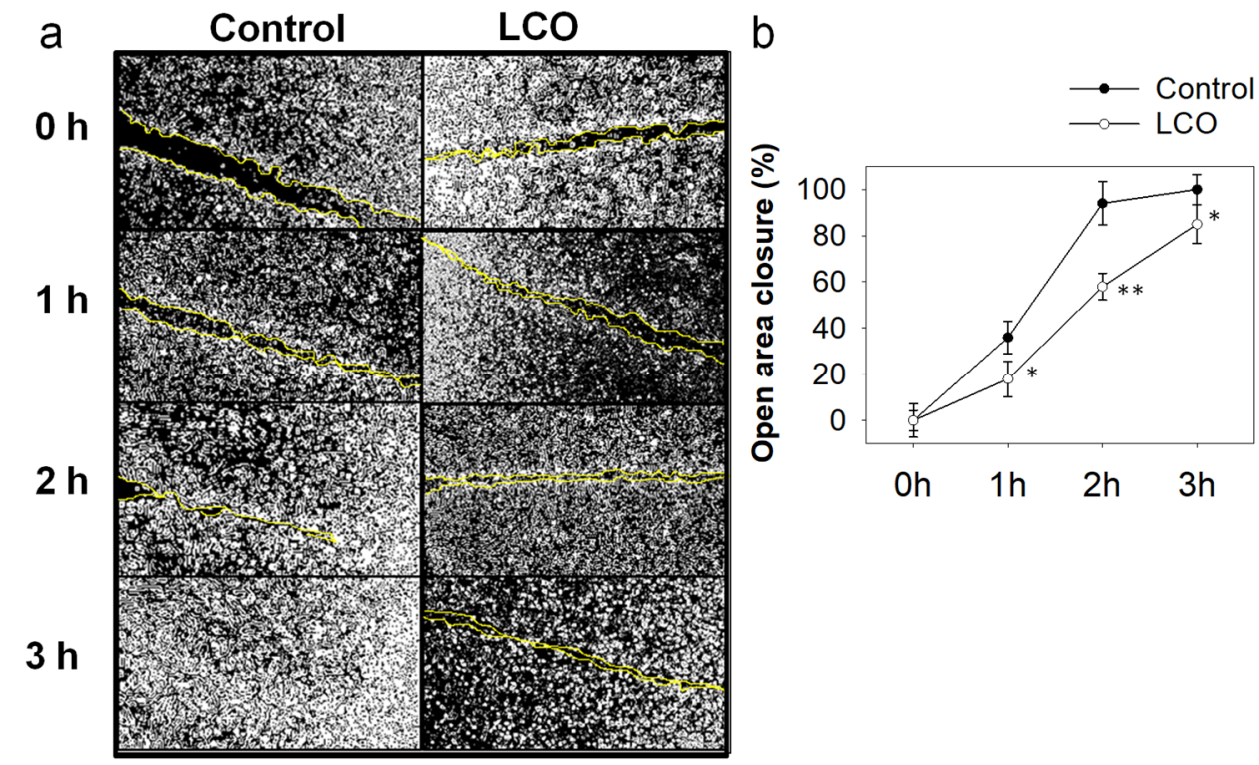

Figure 3. Effect of LCO on migration of cancer cells. Wound-healing assay for DA3 cells treated with $46 \mu \mathrm{g} / \mathrm{mL}$ LCO or DMSO for control. Migration rate of cells was monitored with an optical microscope equipped with a digital camera. (a) Photographs of the wounds captured at the indicated time points. (b) Quantification of the percentage of wound closure was estimated by ImageJ software analysis. Data are presented as the mean \pm SD of three independent experiments. Asterisks indicate statistically significant differences $\left({ }^{*} p<0.05,{ }^{* *} p<0.005\right.$, Student's $t$-test).

Thus, we suggest that a comparative study regarding the antiproliferative and antimigratory activities of citral and LCO be carried out in order to investigate whether citral or a combination of other phytochemicals present in LCO exert the biological reactivity of the oil.

\subsection{Oral Administration of LCO Attenuates Tumor Growth in DA3 Breast Cancer Model in Mice}

Oral administration of LCO for 14 days (Figure $4 \mathrm{a}$ ) induced a statistically significant inhibition in the growth of DA3-tumors in BALB/c mice compared to control animals (Figure 5), while no indications of adverse or toxic effects were observed. Specifically, the daily oral administration of $0.552 \mathrm{~g} / \mathrm{kg}$ of body weight of LCO in female BALB/c mice for 14 days did not affect animal body weight (Figure 4 b) or liver or spleen indexes (Figure 4c,d), which are sensitive indicators for the detection of toxicity in BALB/c mice [54]. Moreover, while animal health was daily monitored for signs of disease or discomfort, no signs of pain or behavioral deviations from normal were detected. Unfortunately, there are no previous studies regarding the in vivo toxicity of the essential oil extracted from L. citriodora. Etemad et al. studied the in vivo toxicological profile of the intraperitoneally administered aqueous extract from the plant and reported that the $\mathrm{LD}_{50}$ in BALB/c mice is $5 \mathrm{~g} / \mathrm{kg}$ of body weight [55], a dose nine times lower than the dose used in our experiments. Moreover, several oral studies on citral, which constitutes $43.6 \%$ of LCO (Table 1), reported no adverse effects for a dose of up to $1.0 \mathrm{~g} / \mathrm{kg}$ animal weight in rodents for an administration period of 14 days to 13 weeks $[56,57]$. 


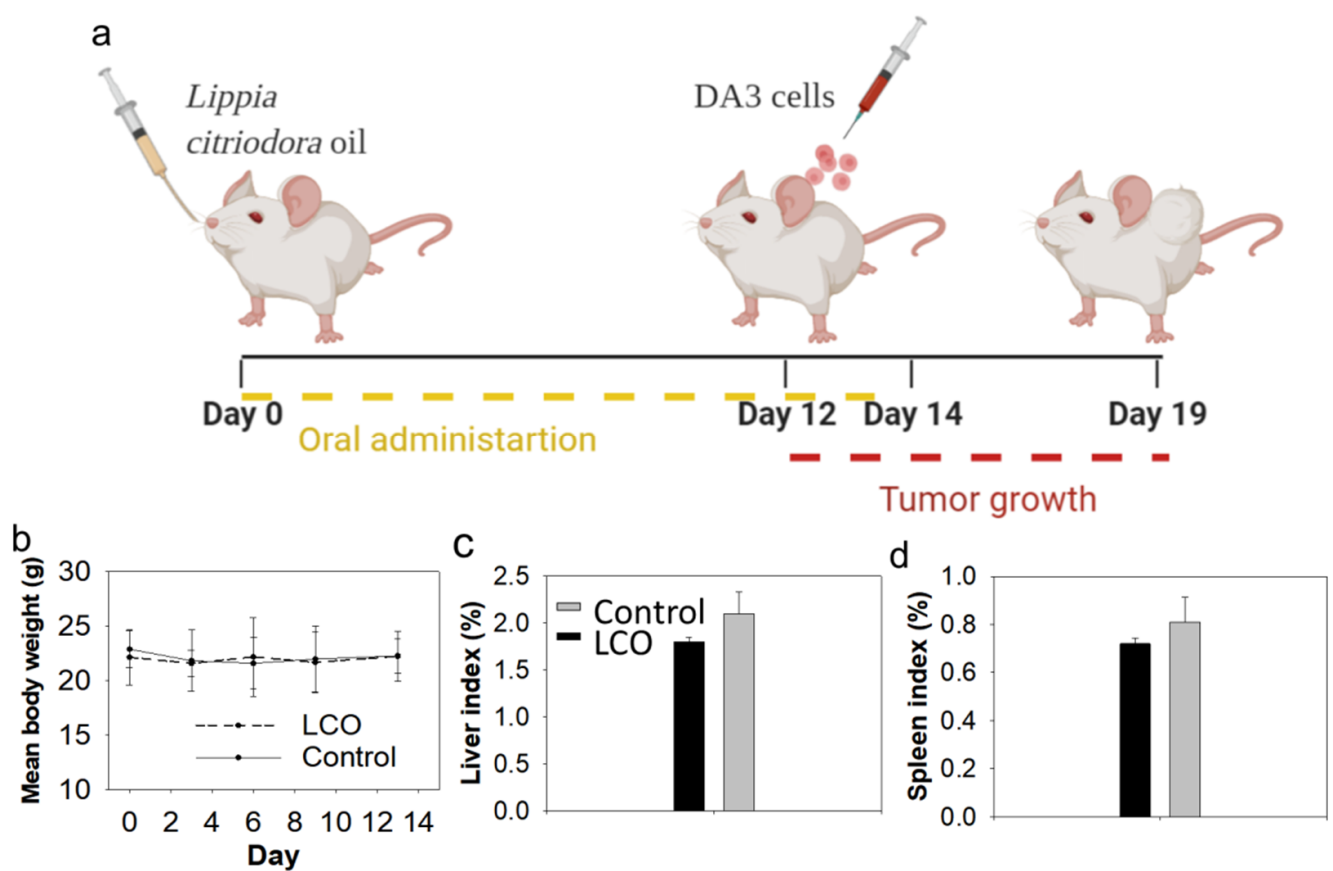

Figure 4. Orally administered LCO in mice is well tolerated. (a) LCO was administered daily to BALB / c mice by oral gavage for 14 days $(0.552 \mathrm{~g} / \mathrm{kg}$ body weight/day). On the 12th day, mice were inoculated subcutaneously with DA3 cancer cells $\left(5 \times 10^{6}\right.$ cells per mouse $)$ and, 7 days later, animals were euthanized. (b) No significant change was observed in animal body weight between LCO-treated and control mice during the LCO administration period. No significant differences were observed between (c) liver- or (d) spleen-weight-to-body-weight ratios between control and LCO-treated mice.

Noteworthy, the administration scheme of LCO, described in Figure 4a, induced a $55 \%$ inhibition in tumor volume in the DA3 breast adenocarcinoma model. In specific, 7 days post cancer cells' inoculation, control animals developed tumors of an average size of $377 \mathrm{~mm}^{3}$, while LCO-treated animals developed tumors of an average size of $170 \mathrm{~mm}^{3}$. To the best of our knowledge, this is the first report on the antitumor potential of orally administered LCO.

\subsection{LCO Increases Cleaved Caspase 3 Levels and Reduces Protein Expression of Survivin (BIRC5a) in DA3 Tumors}

In accordance with our in vitro results (Figure 2), the apoptotic marker cleaved caspase 3 (c-cas3) was elevated in the tumor tissue of LCO-treated animals. In specific, an average of $30 \%$ of cells was positive for active caspase 3 in mice that had been receiving LCO compared to $19 \%$ in control animals (Figure $5 \mathrm{~d}$ ). These results, along with the elevated pro-apoptoticto-live cells' ratios that were detected in vitro in DA3 cells exposed to LCO, indicate that apoptosis might be among the mechanisms initiated by LCO in breast cancer cells. Moreover, protein expression of survivin, a proliferation marker and negative regulator of apoptosis that is highly expressed in most human tumors [58], was reduced by $20 \%$ in the tumor tissue of LCO-treated mice (Figure 5e). 


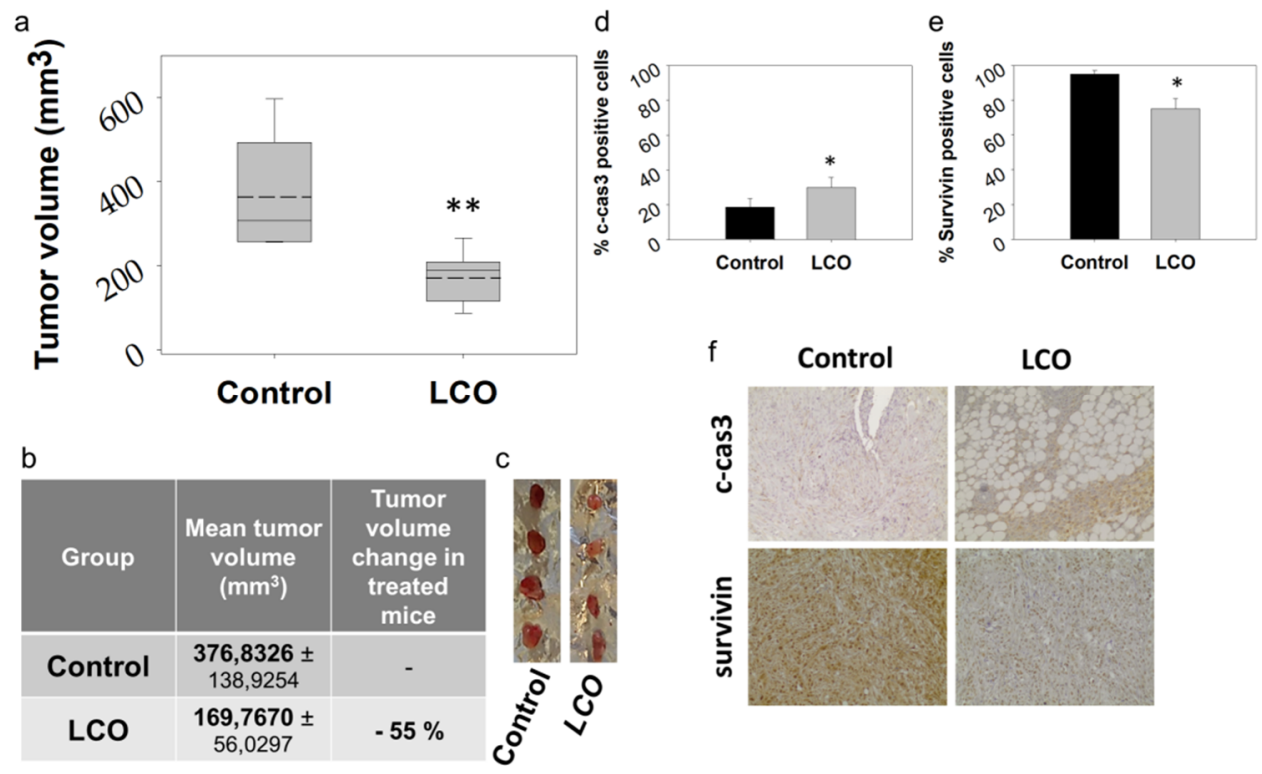

Figure 5. Oral administration of LCO attenuates tumor growth in DA3 breast cancer model in mice. LCO was administered daily to BALB/c mice by oral gavage for 14 days and, on the 12th day, mice were inoculated subcutaneously with DA3 cancer cells $\left(5 \times 10^{6}\right.$ cells per mouse). Seven days later, animals were euthanized and the developed tumors were harvested. A statistically significant reduction of $\approx 55 \%$ in tumor volume ( $p=0.001$, Student's $t$-test) was observed in LCO-treated animals compared to the control group. (a) Graphical representation of tumor volume distribution (solid lines indicate median and dashed lines indicate mean values), (b) mean tumor volume, and (c) photographic observation of excised tumors. (d-f) Immunohistochemical detection of (d) cleaved caspase-3 and (e) survivin in tumor tissue from LCO-treated or control mice. (f) Representative images showing the effect of LCO administration on survivin andc-cas3 protein levels. The differences in the expression of cleaved cas-3 or survivin in tumor tissue from treated versus control mice are statistically significant ( $p=0.023$ or $p=0.024$, respectively), as calculated using the SigmaPlot 11.0 statistical software; $\left({ }^{*} p<0.05,{ }^{* *} p<0.005\right)$.

\section{Conclusions}

Our results provide compelling evidence for the antitumor potential of LCO against breast cancer. We demonstrated that LCO, as a mixture of various phytochemicals with antioxidant activity, inhibits the proliferation of breast cancer cells in vitro and attenuates tumor growth in vivo in a murine breast adenocarcinoma model. In line with the traditional use of the plant in tea infusion preparations, we decided to use oral exposure as the route of LCO administration. Despite the restricted bioavailability due to pre-systemic metabolism, LCO, as a mixture of phytochemicals, induced a 55\% inhibition in tumor volume. Noteworthy, LCO attenuated the migration and proliferation of DA3 breast cancer cells in vitro, partially by inducing apoptotic cell death as evidenced by the Annexin V/PI assay. Moreover, orally administered LCO induced the activation of caspase 3 and downregulated the protein expression of the anti-apoptotic protein survivin in mouse tumor tissue. Taken together, these results confirm the hypothesis that the essential oil extracted from the plant L. citriodora exerts antitumor effects against breast adenocarcinoma and highlight the interest of LCO as a source of bioactive compounds with great nutraceutical potential. LCO's most abundant phytochemical, citral, is a good candidate for further investigation in future studies. 
Author Contributions: Conceptualization, K.C.; methodology, K.S., T.A., and E.L.; validation, K.C., A.P., and E.E.; formal analysis, K.S. and E.L; investigation, K.S., T.A., E.L., and E.E.; writingoriginal draft preparation, K.S. and T.A.; writing-review and editing, K.C.; supervision, K.C.; funding acquisition, K.C. and A.P. All authors have read and agreed to the published version of the manuscript.

Funding: Part of this research project was co-financed by the European Union (European Regional Development Fund-ERDF) and Greek national funds through the Operational Program "National Action "Cooperation 2011-Partnerships of Production and Research Institutions in Focused Research and Technology Sectors" (Project Nr. 11SYN_2_566). Part of the work was implemented by utilizing the facilities of the project "An Open-Access Research Infrastructure of Chemical Biology and TargetBased Screening Technologies for Human and Animal Health, Agriculture and the Environment (OPENSCREEN-GR)" (MIS 5002691), which is implemented under the Action "Reinforcement of the Research and Innovation Infrastructure", funded by the Operational Program "Competitiveness, Entrepreneurship and Innovation" (NSRF 2014-2020) and co-financed by Greece and the European Union (European Regional Development Fund).

Institutional Review Board Statement: The in vivo experimental protocol followed in this study was approved by the Animal Care and Use Committee of the Veterinary Department of Ioannina Prefecture (license number EL20BIO02). All animal procedures were carried out in accordance with the principle of the 3 Rs (replacement, refinement, reduction) and all mice used were not subjected to any pain or discomfort.

Informed Consent Statement: Not applicable.

Data Availability Statement: Supporting data are available from the authors upon request.

Acknowledgments: Scheme in Figure 4a and graphical abstract were prepared with Biorender.

Conflicts of Interest: The authors declare no conflict of interest. The funders had no role in the design of the study; in the collection, analyses, or interpretation of data; in the writing of the manuscript; or in the decision to publish the results.

\section{References}

1. Harborne, J.B. Introduction to Ecological Biochemistry; Elsevier: Amsterdam, The Netherlands, 1993; Volume 6, ISBN 9780080918587.

2. Kennedy, D.O.; Wightman, E.L. Herbal extracts and phytochemicals: Plant secondary metabolites and the enhancement of human brain function. Adv. Nutr. 2011, 2, 32-50. [CrossRef]

3. Thirumurugan, D.; Cholarajan, A.; Raja, S.S.S.; Vijayakumar, R. An Introductory Chapter: Secondary Metabolites. In Secondary Metabolites-Sources and Applications; IntechOpen Limited: London, UK, 2018.

4. Hussein, R.A.; El-Anssary, A.A. Plants Secondary Metabolites: The Key Drivers of the Pharmacological Actions of Medicinal Plants. In Herbal Medicine; IntechOpen Limited: London, UK, 2019.

5. Senthil-Nathan, S. A Review of Resistance Mechanisms of Synthetic Insecticides and Botanicals, Phytochemicals, and Essential Oils as Alternative Larvicidal Agents Against Mosquitoes. Front. Physiol. 2020, 10, 1591. [CrossRef]

6. Mitropoulou, G.; Fitsiou, E.; Spyridopoulou, K.; Tiptiri-Kourpeti, A.; Bardouki, H.; Vamvakias, M.; Panas, P.; Chlichlia, K.; Pappa, A.; Kourkoutas, Y. Citrus medica essential oil exhibits significant antimicrobial and antiproliferative activity. LWT Food Sci. Technol. 2017, 84, 344-352. [CrossRef]

7. Yarmolinsky, L.; Huleihel, M.; Zaccai, M.; Ben-Shabat, S. Potent antiviral flavone glycosides from Ficus benjamina leaves. Fitoterapia 2012, 83, 362-367. [CrossRef] [PubMed]

8. Khan, M.R.; Omoloso, A.D. Antibacterial, antifungal activities of Barringtonia asiatica. Fitoterapia 2002, 73, 255-260. [CrossRef]

9. Tiptiri-Kourpeti, A.; Fitsiou, E.; Spyridopoulou, K.; Vasileiadis, S.; Iliopoulos, C.; Galanis, A.; Vekiari, S.; Pappa, A.; Chlichlia, K. Evaluation of Antioxidant and Antiproliferative Properties of Cornus mas L. Fruit Juice. Antioxidants 2019, 8, 377. [CrossRef]

10. Owolabi, O.O.; James, D.B.; Sani, I.; Andongma, B.T.; Fasanya, O.O.; Kure, B. Phytochemical analysis, antioxidant and antiinflammatory potential of FERETIA apodanthera root bark extracts. BMC Complement. Altern. Med. 2018, 18, 1-9. [CrossRef] [PubMed]

11. Spyridopoulou, K.; Fitsiou, E.; Bouloukosta, E.; Tiptiri-Kourpeti, A.; Vamvakias, M.; Oreopoulou, A.; Papavassilopoulou, E.; Pappa, A.; Chlichlia, K. Extraction, Chemical Composition, and Anticancer Potential of Origanum onites L. Essential Oil. Molecules 2019, 24, 2612. [CrossRef] [PubMed]

12. Spyridopoulou, K.; Tiptiri-Kourpeti, A.; Lampri, E.; Fitsiou, E.; Vasileiadis, S.; Vamvakias, M.; Bardouki, H.; Goussia, A.; Malamou-Mitsi, V.; Panayiotidis, M.I.; et al. Dietary mastic oil extracted from Pistacia lentiscus var. chia suppresses tumor growth in experimental colon cancer models. Sci. Rep. 2017, 7, 3782. [CrossRef] 
13. Fitsiou, E.; Mitropoulou, G.; Spyridopoulou, K.; Tiptiri-Kourpeti, A.; Vamvakias, M.; Bardouki, H.; Panayiotidis, M.I.; Galanis, A.; Kourkoutas, Y.; Chlichlia, K.; et al. Phytochemical profile and evaluation of the biological activities of essential oils derived from the greek aromatic plant species Ocimum basilicum, Mentha spicata, Pimpinella anisum and Fortunella margarita. Molecules 2016, 21, 1069. [CrossRef]

14. Kumar, M.; Kaur, V.; Kumar, S.; Kaur, S. Phytoconstituents as apoptosis inducing agents: Strategy to combat cancer. Cytotechnology 2016, 68, 531-563. [CrossRef]

15. Singh, S.; Sharma, B.; Kanwar, S.S.; Kumar, A. Lead phytochemicals for anticancer drug development. Front. Plant Sci. 2016, 7, 1667. [CrossRef]

16. Banudevi, S.; Swaminathan, S.; Maheswari, K.U. Pleiotropic Role of Dietary Phytochemicals in Cancer: Emerging Perspectives for Combinational Therapy. Nutr. Cancer 2015, 67, 1021-1048. [CrossRef]

17. Wang, S.; Meckling, K.A.; Marcone, M.F.; Kakuda, Y.; Tsao, R. Can phytochemical antioxidant rich foods act as anti-cancer agents? Food Res. Int. 2011, 44, 2545-2554. [CrossRef]

18. Argyropoulou, C.; Daferera, D.; Tarantilis, P.A.; Fasseas, C.; Polissiou, M. Chemical composition of the essential oil from leaves of Lippia citriodora H.B.K. (Verbenaceae) at two developmental stages. Biochem. Syst. Ecol. 2007, 35, 831-837. [CrossRef]

19. Lee, Y.-S.; Yang, W.-K.; Kim, H.; Min, B.; Caturla, N.; Jones, J.; Park, Y.-C.; Lee, Y.-C.; Kim, S.-H. Metabolaid ${ }^{\circledR}$ Combination of Lemon Verbena and Hibiscus Flower Extract Prevents High-Fat Diet-Induced Obesity through AMP-Activated Protein Kinase Activation. Nutrients 2018, 10, 1204. [CrossRef]

20. Santos-Gomes, P.C.; Fernandes-Ferreira, M.; Vicente, A.M.S. Composition of the essential oils from flowers and leaves of vervain [aloysia triphylla (L'Herit.) britton] grown in Portugal. J. Essent. Oil Res. 2005, 17, 73-78. [CrossRef]

21. Naser Aldeen, M.G.; Mansoor, R.; AlJoubbeh, M. Fluctuations of phenols and flavonoids in infusion of lemon verbena (Lippia citriodora) dried leaves during growth stages. Nutr. Food Sci. 2015, 45, 766-773. [CrossRef]

22. Farahmandfar, R.; Asnaashari, M.; Pourshayegan, M.; Maghsoudi, S.; Moniri, H. Evaluation of antioxidant properties of lemon verbena (Lippia citriodora) essential oil and its capacity in sunflower oil stabilization during storage time. Food Sci. Nutr. 2018, 6, 983-990. [CrossRef] [PubMed]

23. Valentão, P.; Fernandes, E.; Carvalho, F.; Andrade, P.B.; Seabra, R.M.; Bastos, M.D.L. Studies on the antioxidant activity of Lippia citriodora infusion: Scavenging effect on superoxide radical, hydroxyl radical and hypochlorous acid. Biol. Pharm. Bull. 2002, 25, 1324-1327. [CrossRef] [PubMed]

24. Villegas-Aguilar, M.d.C.; Leyva-Jiménez, F.J.; Cádiz-Gurrea, M.d.l.L.; Segura-Carretero, A.; Arráez-Román, D. Comprehensive Analysis of Antioxidant Compounds from Lippia citriodora and Hibiscus sabdariffa Green Extracts Attained by Response Surface Methodology. Antioxidants 2020, 9, 1175. [CrossRef] [PubMed]

25. Portmann, E.; Nigro, M.M.L.; Reides, C.G.; Llesuy, S.; Ricco, R.A.; Wagner, M.L.; Gurni, A.A.; Carballo, M.A. Aqueous extracts of Lippia turbinata and Aloysia citriodora (Verbenaceae): Assessment of antioxidant capacity and DNA damage. Int. J. Toxicol. 2012, 31, 192-202. [CrossRef] [PubMed]

26. El-Hawary, S.S.; Yousif, M.F.; Abdel Motaal, A.A.; Abd-Hameed, L.M. Bioactivities, phenolic compounds and in-vitro propagation of Lippia citriodora Kunth cultivated in Egypt. Bull. Fac. Pharm. Cairo Univ. 2012, 50, 1-6. [CrossRef]

27. Fitsiou, E.; Mitropoulou, G.; Spyridopoulou, K.; Vamvakias, M.; Bardouki, H.; Galanis, A.; Chlichlia, K.; Kourkoutas, Y.; Panayiotidis, M.; Pappa, A. Chemical Composition and Evaluation of the Biological Properties of the Essential Oil of the Dietary Phytochemical Lippia citriodora. Molecules 2018, 23, 123. [CrossRef] [PubMed]

28. Escobar, P.; Leal, S.M.; Herrera, L.V.; Martinez, J.R.; Stashenko, E. Chemical composition and antiprotozoal activities of Colombian Lippia spp essential oils and their major components. Mem. Inst. Oswaldo Cruz 2010, 105, 184-190. [CrossRef] [PubMed]

29. Oukerrou, M.A.; Tilaoui, M.; Mouse, H.A.; Bouchmaa, N.; Zyad, A. Differential Cytotoxic Activity of Essential Oil of Lippia citriodora from Different Regions in Morocco. Chem. Biodivers. 2017, 14, e1600497. [CrossRef] [PubMed]

30. Najar, B.; Shortrede, J.E.; Pistelli, L.; Buhagiar, J. Chemical Composition and in vitro Cytotoxic Screening of Sixteen Commercial Essential Oils on Five Cancer Cell Lines. Chem. Biodivers. 2020, 17, e1900478. [CrossRef] [PubMed]

31. Nigjeh, S.E.; Yeap, S.K.; Nordin, N.; Rahman, H.; Rosli, R. In vivo anti-tumor effects of citral on 4T1 breast cancer cells via induction of apoptosis and downregulation of aldehyde dehydrogenase activity. Molecules 2019, 24, 3241. [CrossRef]

32. Nordin, N.; Yeap, S.K.; Rahman, H.S.; Zamberi, N.R.; Mohamad, N.E.; Abu, N.; Masarudin, M.J.; Abdullah, R.; Alitheen, N.B. Antitumor and Anti-Metastatic Effects of Citral-Loaded Nanostructured Lipid Carrier in 4T1-Induced Breast Cancer Mouse Model. Molecules 2020, 25, 2670. [CrossRef]

33. Bray, F.; Ferlay, J.; Soerjomataram, I.; Siegel, R.L.; Torre, L.A.; Jemal, A. Global cancer statistics 2018: GLOBOCAN estimates of incidence and mortality worldwide for 36 cancers in 185 countries. CA Cancer J. Clin. 2018, 68, 394-424. [CrossRef]

34. Yin, L.; Duan, J.J.; Bian, X.W.; Yu, S.C. Triple-negative breast cancer molecular subtyping and treatment progress. Breast Cancer Res. 2020, 22, 1-13. [CrossRef] [PubMed]

35. Gurer-Orhan, H.; Ince, E.; Konyar, D.; Saso, L.; Suzen, S. The Role of Oxidative Stress Modulators in Breast Cancer. Curr. Med. Chem. 2017, 25, 4084-4101. [CrossRef]

36. Griñan-Lison, C.; Blaya-Cánovas, J.L.; López-Tejada, A.; Ávalos-Moreno, M.; Navarro-Ocón, A.; Cara, F.E.; González-González, A.; Lorente, J.A.; Marchal, J.A.; Granados-Principal, S. Antioxidants for the treatment of breast cancer: Are we there yet? Antioxidants 2021, 10, 205. [CrossRef] [PubMed] 
37. Yu, B.; Kusmartsev, S.; Cheng, F.; Paolini, M.; Nefedova, Y.; Sotomayor, E.; Gabrilovich, D. Effective combination of chemotherapy and dendritic cell administration for the treatment of advanced-stage experimental breast cancer. Clin. Cancer Res. 2003, 9 , 285-294.

38. Spyridopoulou, K.; Tryfonopoulou, E.; Aindelis, G.; Ypsilantis, P.; Sarafidis, C.; Kalogirou, O.; Chlichlia, K. Biogenic selenium nanoparticles produced by Lactobacillus casei ATCC 393 inhibit colon cancer cell growth in vitro and in vivo. Nanoscale Adv. 2021, 3, 2516-2528. [CrossRef]

39. Tiptiri-Kourpeti, A.; Spyridopoulou, K.; Santarmaki, V.; Aindelis, G.; Tompoulidou, E.; Lamprianidou, E.E.; Saxami, G.; Ypsilantis, P.; Lampri, E.S.; Simopoulos, C.; et al. Lactobacillus casei Exerts Anti-Proliferative Effects Accompanied by Apoptotic Cell Death and Up-Regulation of TRAIL in Colon Carcinoma Cells. PLoS ONE 2016, 11, e0147960. [CrossRef]

40. Vichai, V.; Kirtikara, K. Sulforhodamine B colorimetric assay for cytotoxicity screening. Nat. Protoc. 2006, 1, 1112-1116. [CrossRef]

41. Haanen, C.; Steffens-nakken, H.; Reutelingsperger, C. A novel assay for apoptosis Flow cytometric detection of phosphatidylserine expression on early apoptotic cells using fluorescein labelled Annexin V. J. Immunol. Methods 1995, 184, 39-51.

42. Bailly, C. Targets and pathways involved in the antitumor activity of citral and its stereo-isomers. Eur. J. Pharmacol. 2020, 871, 172945. [CrossRef]

43. Zhang, Y.; Chen, Y.; Wang, S.; Dong, Y.; Wang, T.; Qu, L.; Li, N.; Wang, T. Bioactive Constituents from the Aerial Parts of Lippia triphylla. Molecules 2015, 20, 21946-21959. [CrossRef] [PubMed]

44. Brahmi, N.; Scognamiglio, M.; Pacifico, S.; Mekhoukhe, A.; Madani, K.; Fiorentino, A.; Monaco, P. 1H NMR based metabolic profiling of eleven Algerian aromatic plants and evaluation of their antioxidant and cytotoxic properties. Food Res. Int. 2015, 76, 334-341. [CrossRef]

45. Cheimonidi, C.; Samara, P.; Polychronopoulos, P.; Tsakiri, E.N.; Nikou, T.; Myrianthopoulos, V.; Sakellaropoulos, T.; Zoumpourlis, V.; Mikros, E.; Papassideri, I.; et al. Selective cytotoxicity of the herbal substance acteoside against tumor cells and its mechanistic insights. Redox Biol. 2018, 16, 169-178. [CrossRef] [PubMed]

46. Thomas, M.L.; de Antueno, R.; Coyle, K.M.; Sultan, M.; Cruickshank, B.M.; Giacomantonio, M.A.; Giacomantonio, C.A.; Duncan, R.; Marcato, P. Citral reduces breast tumor growth by inhibiting the cancer stem cell marker ALDH1A3. Mol. Oncol. 2016, 10, 1485-1496. [CrossRef]

47. Storey, S. Targeting apoptosis: Selected anticancer strategies. Nat. Rev. Drug Discov. 2008, 7, 971-972. [CrossRef] [PubMed]

48. Pavithra, P.S.; Mehta, A.; Verma, R.S. Induction of apoptosis by essential oil from P. missionis in skin epidermoid cancer cells. Phytomedicine 2018, 50, 184-195. [CrossRef]

49. Quassinti, L.; Maggi, F.; Barboni, L.; Ricciutelli, M.; Cortese, M.; Papa, F.; Garulli, C.; Kalogris, C.; Vittori, S.; Bramucci, M. Wild celery (Smyrnium olusatrum L.) oil and isofuranodiene induce apoptosis in human colon carcinoma cells. Fitoterapia 2014, 97, 133-141. [CrossRef]

50. Fitsiou, E.; Pappa, A. Anticancer activity of essential oils and other extracts from aromatic plants grown in Greece. Antioxidants 2019, 8, 290. [CrossRef]

51. Van Zijl, F.; Krupitza, G.; Mikulits, W. Initial steps of metastasis: Cell invasion and endothelial transmigration. Mutat. Res. Rev. Mutat. Res. 2011, 728, 23-34. [CrossRef]

52. Ham, S.L.; Nasrollahi, S.; Shah, K.N.; Soltisz, A.; Paruchuri, S.; Yun, Y.H.; Luker, G.D.; Bishayee, A.; Tavana, H. Phytochemicals potently inhibit migration of metastatic breast cancer cells. Integr. Biol. 2015, 7, 792-800. [CrossRef] [PubMed]

53. Nordin, N.; Yeap, S.K.; Rahman, H.S.; Zamberi, N.R.; Abu, N.; Mohamad, N.E.; How, C.W.; Masarudin, M.J.; Abdullah, R.; Alitheen, N.B. In vitro cytotoxicity and anticancer effects of citral nanostructured lipid carrier on MDA MBA-231 human breast cancer cells. Sci. Rep. 2019, 9, 1614. [CrossRef] [PubMed]

54. Badgujar, P.C.; Jain, S.K.; Singh, A.; Punia, J.S.; Gupta, R.P.; Chandratre, G.A. Immunotoxic effects of imidacloprid following 28 days of oral exposure in BALB/c mice. Environ. Toxicol. Pharmacol. 2013, 35, 408-418. [CrossRef]

55. Etemad, L.; Shirvan, Z.O.; Vahdati-Mashhadian, N.; Moallem, S.A.; Zafari, R.; Hosseinzadeh, H. Acute, subacute, and cell toxicity of the aqueous extract of Lippia citriodora. Jundishapur J. Nat. Pharm. Prod. 2016, 11. [CrossRef]

56. Dieter, M.P.; Goehl, T.J.; Jameson, C.W.; Elwell, M.R.; Hildebrandt, P.K.; Yuan, J.H. Comparison of the toxicity of citral in F344 rats and B6C3F1 mice when administered by microencapsulation in feed or by corn-oil gavage. Food Chem. Toxicol. 1993, 31, 463-474. [CrossRef]

57. Hagan, E.C.; Hansen, W.H.; Fitzhugh, O.G.; Jenner, P.M.; Jones, W.I.; Taylor, J.M.; Long, E.L.; Nelson, A.A.; Brouwer, J.B. Food flavourings and compounds of related structure. II. Subacute and chronic toxicity. Food Cosmet. Toxicol. 1967, 5, 141-157. [CrossRef]

58. Malcles, M.H.; Wang, H.W.; Koumi, A.; Tsai, Y.H.; Yu, M.; Godfrey, A.; Boshoff, C. Characterisation of the anti-apoptotic function of survivin- $\triangle \mathrm{Ex} 3$ during TNF $\alpha$-mediated cell death. Br. J. Cancer 2007, 96, 1659-1666. [CrossRef] [PubMed] 